\title{
Neonatal gastrointestinal involvement and congenital cytomegalovirus
}

\author{
Alessandro Porta,1 Adriana Avanzini,1 Marta Bellini,1 Rosa Maria Crossignani,1 \\ Stefano Fiocchi,2 Stefano Martinelli,2 Luciana Parola1 \\ 1 Pediatric, Neonatal and Neonatal Pathology Units, G. Fornaroli Hospital, Magenta (MI), Civil Hospital \\ of Legnano (MI); ${ }^{2}$ Neonatal Intensive Care Unit, Hospital Niguarda Ca' Granda, Milan, Italy
}

\begin{abstract}
Cytomegalovirus (CMV) is the most common cause of congenital viral infection, affecting 0.2 to $2.3 \%$ of all live births in developed countries. Very low birth weight and extremely low birth weight newborns are at higher risk of symptomatic CMV infection, most commonly secondary and acquired through breast milk. Gastrointestinal involvement is rare in acquired CMV infections, but it could be an important manifestation of postnatal infection in preterm infants admitted to neonatal intensive care units. Early onset of CMV gastrointestinal signs/symptoms is very rare. In a review of the literature it is described in 5 newborns in the first 24 hours of life, and 6 considering the onset in the first week of life. This review describes also a case report of congenital CMV in an immunocompetent newborn with onset of gastrointestinal signs immediately after birth: a possible association between viral infection and enteric manifestations was considered in the differential diagnosis. A review of the literature of the different case reports
\end{abstract}

Correspondence: Alessandro Porta, Pediatric, Neonatal and Neonatal Pathology Unit, G. Fornaroli Hospital, Civil Hospital of Legnano, via Al Donatore di Sangue 50, 20013 Magenta (MI), Italy.

Tel: +39.3333254715 - Fax: +39.0297963322 .

E-mail: alessandro-porta@tiscali.it

Key words: Cytomegalovirus; Congenital viral infection; Gastrointestinal involvement; Neonate.

Conflict of interest: the authors declare no potential conflict of interest.

Contributions: AP looked after the patient described in the case report during admission, reviewed the literature about congenita/postnatal cytomegalovirus and gastrointestinal involvement, drafted the manuscript and approved the final manuscript as submitted. AA, MB, RMC, and SF looked after the patient described in the case report during admission, reviewed and revised the manuscript, and approved the final manuscript as submitted. SM and LP are the heads of the two departments where the patient was admitted. They looked after the patient described in the case report during admission, reviewed and revised the manuscript, and approved the final manuscript as submitted.

Received for publication: 12 March 2016.

Revision received: 22 June 2016.

Accepted for publication: 19 July 2016.

This work is licensed under a Creative Commons Attribution NonCommercial 4.0 License (CC BY-NC 4.0).

(C) Copyright A. Porta et al., 2016

Licensee PAGEPress, Italy

La Pediatria Medica e Chirurgica 2016; 38:134

doi:10.4081/pmc.2016.134 found has done, with description and comparison of the different patients and clinical presentations.

\section{Introduction}

Cytomegalovirus (CMV) is the most common cause of congenital viral infection, affecting 0.2 to $2.3 \%$ of all live births in developed coun-

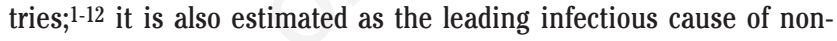
genetic hearing loss, mental retardation 1,2,13-15 and non-genetic congenital malformations. ${ }^{16}$ Very low birth weight and extremely low birth weight newborns are at higher risk of symptomatic CMV infection, most commonly secondary, acquired through breast milk. ${ }^{17}$

Maternal primary CMV infection or reinfection during pregnancy are the cause of neonatal congenital infection, with a mean risk of transmission of $40 \%(24-75 \%), 3,18$ lower in the first three months (36\%) than in the last three months of gestation (78\%).3,19

Considering all the infected newborns, only 5 to $10 \%$ are symptomatic at birth, in particular with neurodevelopmental delay signs and sensorial hearing loss. Among asymptomatic patients, $10 \%$ to $15 \%$ will show developmental disorders, mainly sensory hearing loss.1,2,8,10,11,13,14,20-22 Most of congenital infections (85-90\%) remain asymptomatic:3,16,23 among them, 8 to $15 \%$ will show developmental disorders or sensorial hearing loss. ${ }^{1-3,13,14}$

Possible signs and symptoms of congenital CMV infection with onset at birth are the following:3,16,24 unilateral or bilateral sensorial hearing loss, visual loss, microcephaly, hepatomegaly and/or hepatitis, splenomegaly, thrombocytopenia, jaundice, petechiae, motor defects, mental disability, chorioretinitis, strabismus, optic atrophy, dental defects. Rarely it could present as a severe multi organ dysfunction with polyserositis.

Gastrointestinal involvement is considered very rare in congenital and acquired CMV infection.7,8,10,11,20 On the other hand, CMV gastrointestinal symptoms could be an important manifestation of postnatal infection in patients admitted to neonatal intensive care units ${ }^{25}$ or a manifestation of CMV intestinal disease in immunocompromised patients or patients affected by inflammatory bowel disease. ${ }^{22,26-33} \mathrm{~A}$ rare presentation with intestinal polyps in immunocompetent healthy patients has also been described. ${ }^{34}$

\section{Case Report}

A 2330-g female was born at 37 weeks of gestational age through urgent cesarean delivery, necessary due to alterations in foetal cardiac pulse, decline of growth and ultrasound finding of abnormal bowel distension. During pregnancy, serologic conversion for CMV was docu- 
mented in the third trimester. APGAR score was 2 after the first minute, and 7 at the $5^{\text {th }}$ minute of life.

Due to an important abdominal distension observed immediately after birth, an underlying abdominal pathology was suspected: the patient was promptly transferred to a third level neonatal centre, the neonatal intensive care unit of Niguarda Hospital (Milan, Italy).

Since birth, the baby had passed liquid meconium with subsequent mucus and liquid stools. Radiologic examinations performed immediately after admission showed small-intestinal distension with a widespread intestinal wall thickening. Through thoracic and abdominal Xray, abdominal ultrasound and neonatal-surgery expert advice, surgical pathologies were excluded.

Oral feeding was started on the $3^{\text {rd }}$ day of life, with good tolerance but persistence of liquid stools, suggesting colitis as cause of the symptoms.

Urine and blood were tested for CMV DNA through polymerase chain reaction, yielding positive results (1.296.341 and 2.322 copies $/ \mathrm{mL}$, respectively). All the other examinations carried out to exclude other CMV localizations (ophthalmologic examination, brain ultrasound) were normal. No specific analysis to confirm a possible relation between CMV and enteric symptoms, such as intestinal biopsy, were done, due to the rapid and progressive improvement of the patient. So we hypothesized a possible association between CMV and gastrointestinal involvement, but it was not proven with invasive tests.

On the $7^{\text {th }}$ day of life, the patient was transferred back to our unit. During hospital stay, gastrointestinal symptoms progressively improved until normalization, with good oral feeding tolerance of both maternal and formula milk and a very good growth curve. Moreover, brain and abdominal ultrasonographies were normal. A follow-up brain magnetic resonance was negative. Neurologic development was normal, with a physiologic course. Any antiviral treatment was started.

\section{Discussion}

Congenital CMV is currently considered the most common congenital viral infection, with a prevalence of $0.2 \%$ to $2.3 \%$ in developed countries $^{1-12}$ and 0.57 to $1 \%$ in Italy. 3,35

Even though gastrointestinal involvement due to congenital or immediately post-natal CMV infection has been considered extremely rare, some case reports have been found in the literature. Table 1 summarizes all the case reports and articles found in a review of the liter-

Table 1. Review of the literature: case reports of congenital or postnatal cytomegalovirus infection and gastrointestinal involvement with onset within 90 days of life.

\begin{tabular}{|c|c|}
\hline Article details: author, year (city, country) & Issues \\
\hline Gretillat et al., 1979 (France) ${ }^{36}$ & CMV inclusions in the intestine of an infant with NEC \\
\hline Sann et al., 1981 (France) ${ }^{37}$ & $\begin{array}{l}\text { Of } 11 \text { newborns with NEC, } 7 \text { of them had CMV infection. NEC accounted for } 22 \% \text { of all } \\
\text { clinical manifestations of CMV infection }\end{array}$ \\
\hline Hershlag et al., 1984 (Jerusalem, Isralel) ${ }^{38}$ & CMV infection in a patient with Hirschsprung's disease \\
\hline D’agostino et al., 1988 (Vicenza, Italy) ${ }^{39}$ & Histologic finding of CMV infection in a post-NEC stenosis \\
\hline Fournier et al., 1989 (Lyon-Sud, France) ${ }^{40}$ & CMV cells in a preterm newborn with NEC and colonic stenosis. Onset: $28^{\text {th }}$ day of life \\
\hline Déchelotte et al., 1992 (Clemont Ferrand, France) ${ }^{41}$ & $\begin{array}{l}\text { Three cases of ileal involvement due to CMV infection of foetus and placenta, two of } \\
\text { which with ultrasonography abnormalities of the foetal lower abdomen, and all with CMV } \\
\text { inclusions in intestinal samples }\end{array}$ \\
\hline Huang et al., 1996 (Taoyuna, Taiwan)11 & $\begin{array}{l}\text { Ileal perforation in term newborn with congenital or perinatal CMV. Birth weight } 3500 \mathrm{~g} \text {, onset } \\
\text { at } 42 \text { nd day of life }\end{array}$ \\
\hline Jonkhoff-Slok et al., 1997 (Haarlem, The Netherlands)42 & Diarrhoea and rectal bleeding in a 5-week-old infant with CMV colitis. Born at term \\
\hline Hakim et al., 1997 (Brooklyn, NY, USA) ${ }^{43}$ & Congenital CMV and viral inclusions in ileal ulceration (36 WGA newborn, onset at birth) \\
\hline Reyes et al., 1997 (Orange, CA, USA)22 & $\begin{array}{l}\text { CMV enteritis in a preterm newborn ( } 33 \text { weeks of gestational age, birth weight } 2200 \mathrm{~g} \text { ). Onset } \\
\text { at } 5^{\text {th }} \text { weeks of age }\end{array}$ \\
\hline Stiskal et al., 1997 (New Brunswick, NJ, USA)44 & $\begin{array}{l}\text { Congenital CMV infection with gastrointestinal involvement (necrotizing enterocolitis) in a } 34 \\
\text { WGA, birth weight } 2695 \mathrm{~g} \text {, onset at } 31^{\text {st }} \text { day of life }\end{array}$ \\
\hline Fox et al., 1999 (Farmington, CT, USA) ${ }^{45}$ & $\begin{array}{l}\text { Fever and intractable diarrohea in a } 5 \text { weeks old infant due to CMV-induced enterocolitis. Born } \\
\text { at term }\end{array}$ \\
\hline Quiros-Tejeira et al., 1999 (Los Angeles, CA, USA) ${ }^{46}$ & CMV enterocolitis in an infant, born at term, onset at 60 days of life \\
\hline Asabe et al., 2003 (Fukuoka, Japan)20 & $\begin{array}{l}\text { Pseudo-Hirschsprung's disease and congenital CMV in a term newborn, birth weight } 1952 \mathrm{~g} \text {, } \\
\text { with onset immediately after delivery }\end{array}$ \\
\hline Hinds et al., 2004 (London, UK) ${ }^{47}$ & Bloody diarrhoea due to CMV colitis in a 2-month-old immunocompetent child \\
\hline Rongkavilit et al., 2004 (Detroit, MI, USA)48 & Severe CMV enterocolitis in an immunocompetent infant, birth at term, onset at $60^{\text {th }}$ day of life \\
\hline Gessler et al., 2004 (Zurich, Switzerland) ${ }^{49}$ & $\begin{array}{l}\text { Postnatal CMV infection and CMV-associated enterocolitis in a } 29 \text { WGA newborn, onset at } 6^{\text {th }} \\
\text { day of life, birth weight } 1490 \mathrm{~g}\end{array}$ \\
\hline Cheong et al., 2004 (London, UK)25 & $\begin{array}{l}\text { Description of } 11 \text { infants with postnatal CMV infection and gastrointestinal manifestations } \\
\text { observed in a } 5 \text {-year period }\end{array}$ \\
\hline Ekema et al., 2006 (Brescia, Italy) ${ }^{5}$ & $\begin{array}{l}\text { Colonic stricture mimicking Hirschsprung's disease and congenital CMV in } 37 \text { WGA newborn, } \\
\text { birth weight } 2490 \mathrm{~g} \text {. Onset at } 34^{\text {th }} \text { day of life }\end{array}$ \\
\hline
\end{tabular}

To be continued on next page 
ature. Using PubMed and OVID MEDLINE®, the following key words were searched in titles and abstracts: cytomegalovirus AND colitis or intestine or intestinal or bowel or colic or Hirschsprung AND infant or neonatal or neonate or newborn. Only reports regarding newborns and infants under 3 months of age were considered.

Thirty-eight articles were found up to July 2015. The first report dates back to 1979 , when Gretillat et al. ${ }^{36}$ described a correlation between necrotizing enterocolitis (NEC) and CMV infection, based on inclusion bodies on pathologic examination of bowel specimens.

Most of the studies revealed a possible association between CMV infection and enteritis, ${ }^{22,37,38}$ enterocolitis, ${ }^{25,42,45-51,54-56,59-61,64}$ and NEC, $17,25,33,36,37,39,40,44,63,65$ often with finding of CMV inclusions in histological intestinal samples. It is debatable whether the virus has a role in the pathogenesis of the diseases, either directly or as a secondary super-infection after the acute phase of the enterocolitis. $., 22,39,40,53$

Two articles ${ }^{20,38}$ reported a possible connection between congenital CMV and Hirschsprung's or pseudo-Hirschsprung's disease.

Four other reports $11,38,50,51$ described a possible association between CMV infection and intestinal perforation: two ileal perforations, 11,43 one perforated appendicitis as a complication of CMV enterocolitis ${ }^{51}$ and one Merkel's diverticulum perforation. 50
Déchelotte et al.41 described 3 cases of pseudo-meconium ileus caused by a CMV infection, two of which with antenatal ultrasound detection of increased echogenicity of the lower foetal abdomen.

In a 5 year period, Cheong et al.,25 in the neonatal intensive care units of Queen Charlotte's and Chelsea and Hammersmith Hospitals, identified 16 infants with postnatal CMV infection, eleven of whom with gastrointestinal signs.

Bonnard et al.,50 in a 5-year retrospective study involving neonates operated for gastrointestinal conditions, described the presence of CMV inclusions in five cases: two NEC, two complications of Meckel's diverticulum (volvulus and perforation) and one distal ileal atresia.

A possible correlation between primary colonic stricture and CMV infection was described in three case reports, $5,52,57$ whereas two articles ${ }^{53,66}$ reported an association between ileal stricture and CMV enteritis. Post-necrotizing enterocolitis strictures have been described in three reports. ${ }^{39,40,65}$ Hendriks et al. ${ }^{62}$ described an association between CMV infection and intestinal obstruction without strictures.

When data was available, the onset of gastrointestinal symptoms in the first 24 hours of life $20,43,50,62$ or in the first 7 days of life ${ }^{49}$ was rarely reported and, respectively, in patients with: ileal ulceration, ${ }^{43}$ pseudo-

Table 1. Continued from previous page.

\section{Article details: author, year (city, country)}

Bonnard et al., 2006 (Paris, France) 50

Terry et al., 2006 (Savannah Campus, USA) ${ }^{51}$

Shetty et al., 2007 (Cardiff, UK) ${ }^{52}$

Srinivasjois et al., 2008 (Perth, Australia) ${ }^{53}$

Abdulhannan et al., 2008 (Leeds, UK) 54

Nigro et al., 2010 (L’Aquila, Italy) ${ }^{55}$

Fischer et al., 2010 (Lausanne, Switzerland) ${ }^{56}$

Tzialla et al., 2010 (Pavia, Italy) ${ }^{57}$

Berardi et al., 2011 (Modena, Italy) ${ }^{58}$

Irizarry et al. 2011 (Tampa, FL, USA) $)^{59}$

Bar-Meir et al., 2012 (Chicago, IL, USA) ${ }^{33}$

Refai et al., 2012 (Brighton, UK) ${ }^{60}$

Lee et al. 2012 (Los Angeles, CA, USA) ${ }^{61}$

Unl soy Aksu et al. 2013 (Ankara, Turkey) ${ }^{53}$

Tengsupakul et al., 2013 (Minneapolis, MN, USA) ${ }^{17}$

Tran et al., 2013 (Baton Rouge, LA, USA) ${ }^{63}$

Louazon et al., 2014 (Bron Cedex, France) ${ }^{64}$

Marseglia et al., 2015 (Messina, Italy) 65

\section{Issues}

CMV infections described in 5 neonates operated for gastrointestinal conditions (2 enterocolitis, 2 complications of Merkel's diverticulum, 1 distal ileal atresia). Average WGA 34+4 weeks, average birth weight $2364 \mathrm{~g}$. Onset at 1 to 51 days of life

CMV enterocolitis complicated by perforated appendicitis in a premature infant (30 WGA, onset at 9 weeks of age)

CMV as cause of colonic stricture in a premature infant $(27+2$ WGA, birth weight $490 \mathrm{~g}$, onset at $36^{\text {th }}$ days of life)

CMV-associated enteritis and ileal stricture in a 23+5 WGA preterm newborn, birth weight $580 \mathrm{~g}$, onset at $90^{\text {th }}$ day of life

Primary CMV colitis in a 74 days old infant, born at term

Description of three infants with prenatal or immediately postnatal CMV infection with severe enterocolitis (onset 1-3 months of life)

Acquired postnatal CMV infection in an extremely low birth weight infant, that presented with colitis in a multi-organ syndrome

Large bowel stricture and retinitis due to CMV in an immunocompetent infant, onset at 20th day of life. Born at 37 WGA, birth weight $2490 \mathrm{~g}$

Acquired CMV colitis and anaemia in a 2 months old infant with previous surgery for ileum-caecal valve atresia. Born at term, birth weight $3255 \mathrm{~g}$

Congenitally infected infant with primary CMV enterocolitis, successfully treated with oral valgancyclovir

CMV NEC in 26 WGA premature infant, birth weight, $864 \mathrm{~g}$. Onset: 29 th day of life CMV enterocolitis acquired in the $5^{\text {th }}$ week of life in a term newborn (birth weight $3700 \mathrm{~g}$ )

CMV enterocolitis in a premature newborn $\left(27+4\right.$ WGA, birth weight $1130 \mathrm{~g}$, onset at $34^{\text {th }}$ day of life)

Description of CMV enteritis and jejunal stricture in a preterm infant Hendriks et al., 2013 (Liverpool, UK) ${ }^{62}$ Term newborn, birth weight $3680 \mathrm{~g}$, with perinatal CMV infection, bilious vomiting and abdominal distensions. Onset at $12 \mathrm{~h}$ of life

Postnatal acquired CMV with septic syndrome and NEC in a 24+5 WGA preterm infant, birth weight $800 \mathrm{~g}$, onset in the $5^{\text {th }}$ week of life

NEC and CMV in a premature infant (25+1 WGA, birth weight $653 \mathrm{~g}$ ). Onset at $48^{\text {th }}$ day of life but history of feeding difficulties after the first week of life

CMV enterocolitis, onset at 10 weeks of age. Term infant, birt weight $3150 \mathrm{~g}$

Acquired CMV infection in a term newborn with NEC and consequent colonic stenosis. Birth weight $2780 \mathrm{~g}$, onset at 8 th day of life

CMV, cytomegalovirus; NEC, necrotizing enterocolitis; WGA, weeks for gestational age. 
Hirschsprung's disease, ${ }^{20}$ Merkel's diverticulum perforation, 50 ileal atresia, ${ }^{50}$ intestinal obstruction ${ }^{62}$ and enterocolitis. ${ }^{49}$

The review of the literature suggests that is important to suspect CMV as possible etiologic cause of gastrointestinal symptoms with unknown origin in newborns. The diagnosis of congenital CMV can be done with urine analysis for CMV DNA, a non-invasive and accurate test.

The treatment of congenital CMV infection remains an open and debatable field. While there is agreement to treat CMV positive cases with neurological involvement, and avoiding treatment of CMV positive but asymptomatic patients, the necessity to treat CMV positive newborns with non-neurologic symptoms is controversial. It's also debatable the real necessity to do the intestinal biopsy in suspected cases, since it is invasive and with uncertain utility on clinical practice.

\section{Conclusions}

Gastrointestinal involvement during congenital and post-natal CMV infection is uncommon, in particular in immunocompetent and physiologic newborns. Particularly rare is the onset of these manifestations in the first $24 \mathrm{~h}$ of life. The possible association between congenital infection and gastrointestinal involvement has to be suspected in newborns with specific symptoms and unknown origin. The role of invasive tests, such as the intestinal biopsy, and the necessity of a specific antiviral treatment should be considered accurately on each single case, basing also on the review of the literature and recent scientific evaluations.

\section{References}

1. Picone 0, Teissier N, Cordier AG, et al. Detailed in utero ultrasound description of 30 cases of congenital cytomegalovirus infection. Prenatal Diag 2014;34:518-24.

2. Picone 0, Vauloup-Fellous C, Cordier AG, et al. A series of 238 cytomegalovirus primary infections during pregnancy: description and outcome. Prenatal Diag 2013;33:751-8.

3. Lanzarotto T, Guerra B, Lanari M. Infezione congenita da citomegalovirus umano. Proposta di percorso diagnostico presentato durante il XXXVIII AMCLI (Associazione Microbiologi Clinici Italiani), Rimini, 17-20 November 2009. Available [in Italian] from: www.amcli.it/wp-content/uploads/2015/10/01_Lazzarotto_CMV_ 20100303.pdf

4. Mocarski ES, Shenk T, et al. Cytomegalovirus. In: DM Knipe, PM Howley, eds. Fields virology. Philadelphia, PA. Lippincott Williams and Wilkins; 2007. pp. 2701-72.

5. Ekema G, Pedersini P, Militanti S, et al. Colic stricture mimicking Hirschsprung's disease: a localized cytomegalovirus infection. J Pediatr Surg 2006;41:850-2.

6. Weller TH. The cytomegalovirus: ubiquitous agents with protean manigestations. New Engl J Med 1971;285:203-14.

7. Stagno S. Cytomegalovirus. In: JS Remington, JO Klein, eds. Infectious diseases of the fetus and newborn infant. 3rd edition. Philadelphia, PA: WB Saunders; 1990. pp. 241-81.

8. Peckham CS. Cytomegalovirus infection: congenital and neonatal disease. Scand J Infect 1991;78:82-7.

9. Mustafa MM. Cytomegalovirus infection and disease in the immunocompromised host. Pediatr Infect Dis J 1994;13:249-59.

10. Istas AS, Demmler GI, Dobbin JG, et al. National Congenital Cytomegalovirus Disease Registry Collaborating Group: surveillance for congenital cytomegalovirus disease: a report from the National Congenital Cytomegalovirus Disease Redistry. Clin Infect Dis 1995;20:665-70.
11. Huang YC, Lin TY, Huang CS, Hseun C. Ileal perforation caused by congenital or perinatal cytomegalovirus infection. J Pediatrics 1996;129:931-4.

12. Fjaer RB, Abrahamsen TG, Bruu AL, Hansen TW. Cytomegalovirus infection in neonates. Diagnosis and therapeutic expedience. Tidsskr Nor Laegeforen 1997;117:1460-4.

13. Dollard SC, Grosse SD, Ross DS. New estimates of the prevalence of neurological and sensory sequelae and mortality associated with congenital cytomegalovirus infection. Rev Med Virol 2007;17:355-63.

14. Stagno S. Cytomegalovirus infection: a pediatrician's perspective. Curr Probl Pediatr 1986;16:629-67.

15. Lazzarotto T, Gabrielli L, Guerra B, et al. Diagnosis and prognosis of congenital CMV infection: a case report and review of the literature. Scand J Clin Lab Invest Suppl 2014;244:34-40.

16. Hamilton ST, van Zuylen W, Shand A, et al. Prevention of congenital cytomegalovirus complications by maternal and neonatal treatments: a systematic review. Rev Med Virol 2014;24:420-33.

17. Tengsupakul S, Bridge ND, Bendel CM, et al. Asymptomatic DNAemia heralds CMV-associated NEC: case report, review and rationale for preemption. Pediatrics 2013;132:e1428-34.

18. Fowler KB, Stagno S, Pass RF, et al. The outcome of congenital cytomegalovirus in relation to maternal antibody status. New Engl J Med 1992;326:663-7.

19. Revello MG, Gerna G. Diagnosis and management of human cytomegalovirus infection in the mother, fetus, and newborn infant. Clin Microbiol Review 2002;15:680-715.

20. Asabe K, Nagasaki A, Sato K, et al. Intestinal obstruction caused by congenital cytomegalovirus infection: report of a case. Surg Today 2003;33:764-7.

21. Miesel RL, Alvarez M, Lynch L, et al. Fetal cytomegalovirus infection: a case report. Am J Obstet Gynecol 1990;162:663-4.

22. Reyes C, Pereira S, Warden MJ, et al. Cytomegalovirus enteritis in a premature infant. J Pediatr Surg 1997;32:1545-7.

23. McMullan BJ, Palasanthiran P, Jones CA, et al. Congenital cytomegalovirus - time to diagnosis, management and clinical sequelae in Australia: opportunities for earlier identification. Med J Australia 2011;194:625-9.

24. Stagno S, Pass RF, Dworsky ME, Alford CA. Congenital and perinatal cytomegalovirus infections. Sem Perinat 1983;7:31-42.

25. Cheong JLY, Cowan FM, Modi N. Gastrointestinal manifestations of postnatal cytomegalovirus infection in infants admitted to a neonatal intensive care unit over a five year period. Arch Dis Child Fetal Neonatal Ed 2004;89:F367-9.

26. Ganzenmueller T, Kluba J, Becker JU, et al. Detection of cytomegalovirus (CMV) by real-time PCR in fecal samples for the non-invasive diagnosis of CMV intestinal disease. J Clin Virol 2014;61:517-22.

27. Gauss A, Rosenstiel S, Schnitzler P, et al. Intestinal cytomegalovirus infection in patients hospitalized for exacerbation of inflammatory bowel disease: a 10-year tertiary referral center experience. Eur J Gastroenterol Hepatol 2015;27:712-20.

28. Schwarz DL, So HB, Bungarz WR, et al. A case of life-threatening gastrointestinal hemorrhage in an infant with AIDS. J Pediatr Surg 1989;24:313-5.

29. Dolgin SE, Larsen JG, Kumudini DS, et al. CMV enteritis causing hemorrhage and obstruction in an infant with AIDS. J Pediatr Surg 1990;25:696-8.

30. Mellon A, Shepherd RW, Faoagali JL, et al. Cytomegalovirus infection after liver transplantation in children. J Gastroenterol Hepatol 1993;8:540-4.

31. Huang KY, Lai MW, Lee WI, Huang YC. Fatal cytomegalovirus gastrointestinal disease in an infant with Wiskott-Aldrich syndrome. J Formos Med Assoc 2008;107:64-7.

32. McLoughlin LC, Nord KS, Joshi VV, et al. Severe gastrointestinal 
involvement in children with the acquired immunodeficiency syndrome. J Pediatr Gastroenterol Nutr 1987;6:517-24.

33. Bar-Meir M, Farrow KN, Melin-Aldana H, Chadwick EG. Cytomegalovirus enterocolitis mimicking necrotizing enterocolotis: case report and review of the literature. J Pediatr Infect Dis Soc 2012;22:1-5.

34. Agaimy A, Mudter J, Märkl B, Chetty R. Cytomegalovirus infection presenting as isolated inglammatory polyps of the gastrointestinal tract. Pathology 2011;43:440-6.

35. Kenneson A, Cannon MJ. Review and meta-analysis of the epidemiology of congenital cytomegalovirus (CMV) infection. Rev Med Virol 2007;17:253-76.

36. Gretillat F, Debray P, Mselati JC, et al. Cytomegalic inclusions in the gastrointestinal tract of an infant with enterocolitis. Nouv Presse Med 1979;8:2757.

37. Srinivasjois RM, Kava MP, Thomas A, Rao SC. Cytomegalovirusassociated ileal stricture in a preterm neonate. J Paediatr Child $\mathrm{H}$ 2008;44:80-2.

38. Unlüsoy Aksu A, Sari S, Karabulut R, et al. Jejunal stricture in a premature infant: is cytomegalovirus the causative pathogen or a superinfection? Turk J Gastroenterol 2013;24:273-6.

39. Jonkhoff-Slok TW, Veenhoven RH, de Graeff-Meeder ER, Büller HA. An innumocompetent infant with cow's milk allergy and cytomegalovirus colitis. Eur J Pediatr 1997;156:528 -9.

40. Fox LM, Gerber MA, Penix L, et al. Intractable diarrhea from cytomegalovirus enterocolitis in an immunocompetent infant. Pediatrics 1999;103:E10.

41. Quiros-Tejeira RE, Ament ME, Rivera-Penera T, et al. Cytomegalovirus enterocolitis in an immunocompetent infant host: another cause of treatable intractable diarrhea in infancy. $\mathrm{J}$ Pediatr Gastroenterol Nutr 1999;29:86-90.

42. Rongkavilit C, Bedard MP, Ang JY, et al. Severe cytomegalic enterocolitis in an immunocompetent infant. Pediatr Infect Dis J 2004;23:579-81.

43. Hinds R, Brueton MJ, Francis N, Fell JM. Another cause of bloody diarrhea in infancy: cytomegalovirus colitis in an immunocompetent child. J Pediatr Child Health 2004;40:581-2.

44. Gessler P, Bischoff GA, Wiegand D, et al. Cytomegalovirus-associated necrotizing enterocolitis in a preterm twin after breastfeeding. J Perinatol 2004;24:124-6.

45. Terry NE, Fowler CL. Cytomegalovirus enterocolitis complicated by perforated appendicitis in a premature infant. J Pediatr Surg 2006;41:1476-8.

46. Bonnard A, Le Huidoux P, Carricaburu E, et al. Cytomegalovirus infection as possible underlying factor in neonatal surgical conditions. J Pediatr Surg 2006;41:1826-9.

47. Abdulhannan P, Sugarman ID, Wood P, Puntis JW. Primary CMV colitis in an immunocompetent infant, successfully treated by ganciclovir. J Pediatr Gastroenterol Nutr 2008;47:203-5.

48. Nigro G, Pietrobattista A, Divito S, Gambarara M. Oral ganciclovir therapy for immunocompetent infants with cytomegalovirus-associated hemorrhagic or intractable enterocolitis. J Pediatr Gastroenterol Nutr 2010;50:111-3.
49. Fischer C, Meylan P, Bickle Graz M, et al. Severe postnatally acquired cytomegalovirus infection presenting qith colitis, pneumonitis and sepsis-like syndrome in an extremely low birthweight infant. Neonatology 2010;97:339-45.

50. Berardi A, Rossi C, Fiorini V, et al. Severe acquired cytomegalovirus infection in a full-term, formula-fed infant: case report. BMC Pediatr 2011;11:52.

51. Irizarry K, Honigbaum S, Demmler-Harrison G, et al. Successful treatment with oral valganciclovir of primary CMV enterocolitis in a congenitally infected infant. Fetal Pediatr Pathol 2011;30:437-41.

52. Refai Z, Nicholls S, Garg A. Infant death due to CMV enterocolitis. BMJ Case Reports 2012;2012:14.

53. Lee SL, Johnsen H, Applebaum H. Cytomegalovirus enterocolitis presenting as abdominal compartment syndrome in a premature neonate. World J Pediatr 2012;8:80-2.

54. Louazon T, Collardeau S, Lachaux A. Cytomegalovirus colitis in an immunocompetent child. Arch Pediatr 2014;21:1016-9.

55. Sann L, Aymard M, Gibert R, et al. Necrotizing enterocolitis and cytomegalovirus infection. Nouv Presse Med 1981;10:2495-9.

56. D’Agostino S, Stracca-Pansa V, Drei F, et al. Post-necrotizing enterocolitis stenosis of the colon associated with cytomegalovirus infection. Description of a clinical case. Pediatr Med Chir 1988;10:637-9.

57. Fournier V, Gallet S, Rebaud P, et al. Ulcero-Necrotizing enterocolitis: the role of cytomegalovirus. Apropos of a case. Pediatrie 1989;44:189-92.

58. Stiskal J, Jacquette M, Kaplan G, et al. Congenital cytomegalovirus infection with gastrointestinal involvement. J Pediatr 1997;131:168.

59. Tran L, Ferris M, Norori J, et al. Necrotizing enterocolitis and cytomegalovirus infection in a premature infant. Pediatrics 2013; 131:e318-22.

60. Marseglia L, Manti S, D’Angelo G, et al. Colonic stenosis postnecrotizing enterocolitis in term newborn with acquired cytomegalovirus infection. Chirurgia 2015;110:175-8.

61. Hershlag A, Ariel I, Lernau 0Z, et al. Cytomegalic inclusion virus and Hirschsprung's disease. Z Kinderchir 1984;39:253-4.

62. Hakim A, Mimouni F, Payandeh F, Morawski J. Immunochemical staining in congenital cytomegalovirus-induced ileal ulceration. J Pediatr 1997;131:168-70.

63. Déchelotte PJ, Mulliez NM, Bouvier RJ, et al. Pseudo-meconium ileus due to cytomegalovirus infection: a report of three cases. Pediatr Pathol 1992;12:73-82.

64. Shetty A, Barnes R, Lazda E, et al. Cytomegalovirus: a cause of colonic stricture in a premature infant. J Infect 2007;54:e37-9.

65. Tzialla C, Decembrino L, Di Comite A, et al. Colonic stricture and retinitis due to cytomegalovirus infection in an immunocompetent infant. Pediatr Int 2010;52:659-60.

66. Hendriks G, McPartland J, El-Matary W. Gastrointestinal presentation and outcome of perinatal cytomegalovirus infection. BMJ Case Reports 2013;2013:4. 